PressAcademia Procedia

YEAR 2020 VOLUME 12

Istanbul Finance Congress, November 5-6, 2020

\title{
MILITARY SPENDING AND GROWTH: THE POST-COVID-19 NEW NORMAL IN JORDAN
}

\author{
DOI: 10.17261/Pressacademia.2020.1348 \\ PAP- V.12-2020(12)-p.55-59
}

Ahmad Tarawneh ${ }^{1}$, Muhanned Obeidat ${ }^{2}$, Mohammad Khataybeh ${ }^{3}$, Ghassan Omet ${ }^{4}$

${ }^{1}$ University of Jordan, Department of Finance, Amman, Jordan. ah.altarawneh@ju.edu.jo, ORCID:0000-0002-5833-1887

2 University of Jordan, Department of Finance, Amman, Jordan. mu.obeidat@ju.edu.jo, ORCID:0000-0002-8988-1291

3 University of Jordan, Department of Finance, Amman, Jordan. khataybeh@ju.edu.jo, ORCID:0000-0003-3599-903X

${ }^{4}$ University of Jordan, Department of Finance, Amman, Jordan. gomet@ju.edu.jo, ORCID:0000-0002-8988-1387

\section{To cite this document}

Tarawnet, A., Obeidat, M., Khataybeh, M., Omet, G., (2020). Military spending and growth: the post-covid-19 new normal in Jordan. PressAcademia Procedia (PAP), V.12, p.55.59.

Permanent link to this document: http://doi.org/10.17261/Pressacademia.2020.1348

Copyright: Published by PressAcademia and limited licensed re-use rights only.

\section{ABSTRACT}

Purpose - COVID-19 has forced governments to implement fiscal policy measures that will widen budget deficits in many countries. Economies with limited public revenues or limited fiscal space, like Jordan, will probably suffer more, and probably for years to come. The expected deterioration in the status of public finance will force the government in Jordan to make difficult choices in the re-allocation of its budgetary resources. Within this context, the fact that Jordan has always been a relatively big spender on the military, the pandemic might lead to some decrease in this spending item. This is why the objective of this paper examines the impact of military spending on economic growth in Jordan.

Methodology - To examine the nexus between military spending and economic growth, this paper uses annual data that covers the period 1980 - 2019. The variables used in the analysis are real Gross Domestic Product (GDP), real military spending, and real bank credit to the private sector. As for the methodology, time series techniques are used and these include stationarity tests, co-integration and the long run relationship.

Findings - The impact of military spending on real economic growth is negative. The impact of bank credit to the private sector, on the other hand, is positive and significant. In addition, the results indicate that that bank credit to the private sector reflects increasing importance in explaining the variability in real economic growth over time.

Conclusion - The fact that military spending is relatively high, and its impact on growth is negative, policy makers might be tempted to shift financial resources from this sector to other such as health and education. However, such a decision would not be easy given the fact that Jordan is located in a politically and security unstable environment. After all, military spending the lack of security can be a major impediment to growth and development.

Keywords: Jordan, military spending, growth, bank credit, co-integration.

JEL Codes: H30, H6O, H62

\section{INTRODUCTION}

Soon after its emergence, COVID-19 has become the issue of the day. The virus has hit the largest economies in the world. It has forced nations to adopt lockdown measures. The virus has disrupted the supply side and demand sides of economic activity. In addition, COVID-19 has led governments to adopt various, and arguably, unprecedented monetary policy and fiscal policy measures. The adopted measures will increase public spending levels and decrease public revenues. In other words, budget deficits will increase. Countries with limited fiscal space, their public debt will probably rise to the extent that their budgets will be under pressure for many years to come.

The socio-economic implications of COVID-19 to public finances, notwithstanding, no Jordanian government, since 1965, has managed to realize a surplus in its budget. For example, the period 2012-2019 witnessed an average budget deficit equal to 7.2 percent of GDP (Ministry of Finance / General Government Bulletins). Within this context, it is interesting to note two observations. First, before the onslaught of COVID-19, total public debt stood at 96.7 percent of GDP. Second, during the period 2012-2019, military spending in Jordan was equivalent to 15.6 percent of total public spending, and 4.6 percent of GDP. 
The expected widening in Jordan's budget deficit and the rise in public debt will force the Jordanian government to make some difficult choices. The government may well re-examine its policy priorities and hence, re-allocate some of its spending items. The pandemic might lead to some decrease in military spending in Jordan.

This paper looks the economics of Jordan's military spending. First, few observations about military spending in Jordan, and in other countries, are outlined. Second, using the period $1980-2019$, the main objective of this paper is to examine the nexus between economic growth and military spending in Jordan. In section two, we briefly review the literature. In section 3, we discuss the data and methodology. In section 4, we present and discuss the results. In section 5, we summarize and conclude the paper.

\section{MILITARY SPENDING AND GROWTH: LITERATURE REVIEW}

For a long time, military spending has been attracting a lot of research attention. On average, the literature argues that military spending affects economic growth through demand, supply, and security channels (Dunne et al., 2005).

The demand channel argument is the Keynesian multiplier. In economies with some spare capacity, an increase in military spending increases aggregate demand and hence, results in higher economic growth. Military spending, on the other hand, might crowd-out public as well as private investment. The extent of this impact (crowding-out) depends on, not only the prevailing spare capacity, but also on the source of financing the extra military spending. The financing source might be a decrease in other public spending, increase in taxes, increase in public debt, or even increase the money supply itself.

The supply channel of military spending rests on its spillover impact. For example, new technologies, developed by the military, can have spill over impacts on the rest of the economy at large. Finally, the security channel of military spending rests on protecting people, property, and factors of production in general. Security, after all, maintains security, enables markets to function properly, and promotes investment. Lack of security, on the other hand, destroys growth and development.

The absence of a theoretical agreement notwithstanding, too many empirical papers examine, among others, the impact of military spending on economic growth. This literature examines the relationship at country-level and cross-country level.

As far as military spending in the Middle East is concerned, Lebovic and Ishaq (1987) use 20 Middle Eastern countries (1973-1982) to examine the impact of military spending on growth. Based on their panel data analysis, they report a negative impact. Yildirim et al (2005) examine this issue as well. Their results, based on a panel of 13 Middle Eastern countries (1983 - 1999) and dynamic panel estimations show that the military promotes economic growth. Other papers examine the nexus between military spending and growth at the individual-country level. For example, DeRouen (2000) investigates this issue using relevant data from Israel only. While DeRouen reports a negative impact in the Israeli case, Sezgin (2000) and Yildirim and Sezgin (2002) report a positive impact in the case of Turkey. In addition, Abu-Bader and Abu-Qarn (2003) use Egypt, Israel and Syria in their analysis and report a negative impact of military spending on growth in all three countries.

More recent published papers include Aurelien and Jean-Claude (2018), Aurelien et al. (2019), and Mohanty et al. (2020). Aurelien and JeanClaude (2018) use vector auto-regression (VAR) modeling (1985-2015) and their results, for the case of Chad, show that military expenditure negatively affects economic growth. Aurelien et al. (2019) apply their analysis to a group of 41 African countries (20 stable and 21 unstable). Based on the period 1990 - 2017, and the Generalized Method of Moments (GMM) analysis, they state that military spending negatively and affects economic growth in both sets of countries. Mohanty et al. (2020) investigate the relationship between economic growth and military expenditure in the Indian economy (1970 - 2016). Using the autoregressive distributed lag and Toda-Yamamoto Granger causality analysis, they results report a positive impact.

\section{THE DATA AND METHODOLOGY}

This paper examines the impact of military spending on real economic growth in Jordan during the period 1980-2019. To examine this issue, we specify model (1):

$\mathrm{GDP}_{\mathrm{t}}=\lambda+\beta$ MILITARY $\mathrm{t}+\psi \mathrm{CREDIT}+\varepsilon_{\mathrm{t}}$

where, GDP is real GDP, MILITARY is real military spending, and CREDIT is real bank credit to the private sector. All three variables are in their logarithmic form. The expected signs of the estimated parameters are $\lambda>0, \beta>0, \psi>0$. The error term ( $\varepsilon$ ) is assumed to be independently and identically distributed. The subscript (t) denotes time (1980-2019).

To proceed in our analysis, we first test the data for their stationarity, and then determine the optimal lag structure. Following this, we examine the co-integrating relationship among the variables using the Johansen-Masulius procedures. This co-integration is tested using the maximum eigenvalue $\left(\lambda_{\max }\right)$ and the trace test $\left(\lambda_{\text {trace }}\right)$.

$\lambda_{\max }=-\mathrm{T} \log \left(1-\lambda_{\mathrm{r}+1}\right)$

where the suitable null is $r=g$ co-integrating vectors with $(g=0,1,2,3, \ldots)$ against the alternative which is $r \leq g+1$.

$\lambda_{\text {trace }}=-\mathrm{T} \sum_{i=r+1}^{k} \log \left(1-\lambda_{\mathrm{i}}\right)$

where, the null is $r=g$ against the general specification $r \leq 1$.

Finally, we estimate a vector error-correction (VEC) model to examine the long-run relationship between the variables, and variance decomposition to examine the importance of both military spending and bank credit in explaining the variability of economic growth over time. 
$\Delta \mathrm{GROWTH}_{\mathrm{t}}=\alpha+\lambda e_{\mathrm{t}-1}+\sum_{i=1}^{n} b \mathrm{i} \Delta \mathrm{GROWTH}_{\mathrm{t}-\mathrm{i}}+\sum_{i=1}^{m} \mathrm{Ci}_{\mathrm{i}} \mathrm{MILITARY}_{\mathrm{t}-\mathrm{i}}+\sum_{i=1}^{p} e \mathrm{i} \Delta \mathrm{CREDIT}_{\mathrm{t}-\mathrm{i}}+\varepsilon_{\mathrm{t}}$

\section{MILITARY SPENDING IN JORDAN: SOME OBSERVATIONS AND EMPIRICAL RESULTS}

Based in Sweden, the Stockholm International Peace Research Institute (SIPRI) is an independent institute that focuses its research effort on subjects like general security, conflict and peace, arms control, and armament and disarmament. In addition, SIPRI maintains "The SIPRI Military Expenditure Database". This database contains time series data on the military spending of countries since 1949. From this database, two observations about Jordan's military spending are worth raising.

a. Without going into the details of the political and military environment at that time (Arab-Israeli Conflict), Jordan spent huge amounts on the military during the period 1060-1980. Since 1980, however, and relative to Gross Domestic Product (GDP), this ratio has been consistently falling (Figure 1).

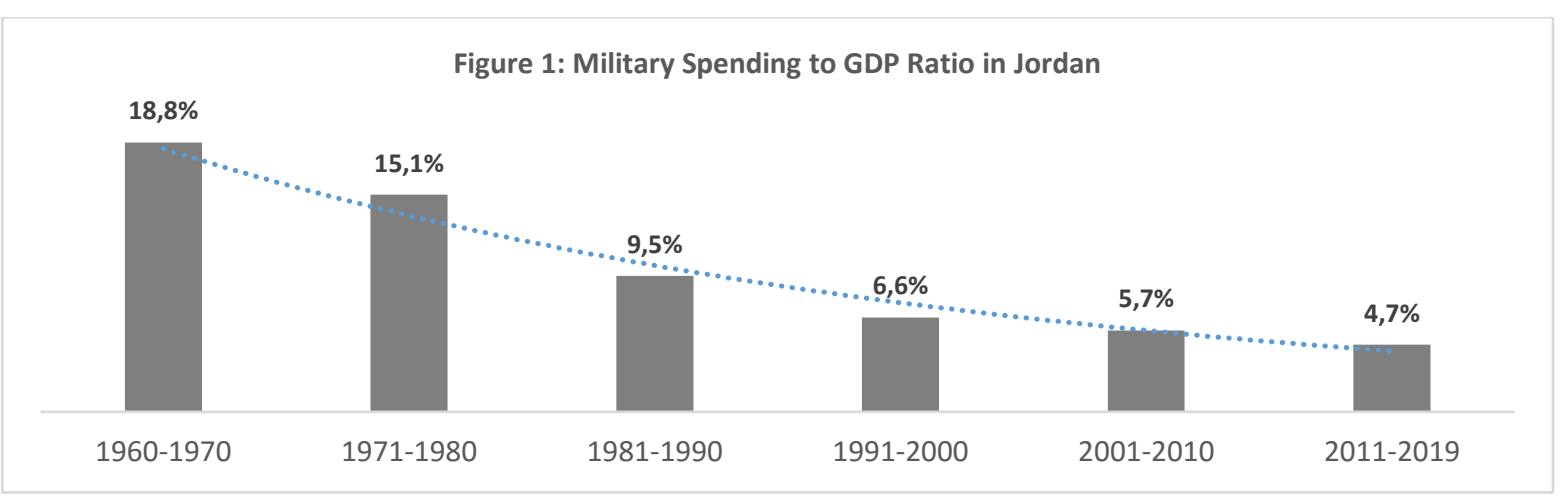

b. In 2019, and relative to GDP, Oman was the largest military spender in the world. Jordan remains one of the high spending Arab countries.

Table 1: Regional, International, and Local Spending on the Military

\begin{tabular}{|l|l|l|l|l|l|}
\hline \multicolumn{2}{|c|}{ Low Spenders } & \multicolumn{2}{c|}{ Medium Spenders } & \multicolumn{2}{c|}{ High Spenders } \\
\hline Switzerland & $0.7 \%$ & Iran Spending to GDP Ratio (2019) & $2.3 \%$ & Pakistan & $4.0 \%$ \\
\hline Japan & $0.9 \%$ & Tunisia & $2.6 \%$ & Lebanon & $4.2 \%$ \\
\hline Egypt & $1.2 \%$ & Turkey & $2.7 \%$ & Jordan & $4.7 \%$ \\
\hline Germany & $1.3 \%$ & Morocco & $3.1 \%$ & Israel & $5.3 \%$ \\
\hline Finland & $1.5 \%$ & USA & $3.4 \%$ & Kuwait & $5.6 \%$ \\
\hline UK & $1.7 \%$ & Iraq & $3.5 \%$ & Algeria & $6.0 \%$ \\
\hline France & $1.9 \%$ & Bahrain & $3.7 \%$ & Saudi Arabia & $8.0 \%$ \\
\hline China & $1.9 \%$ & Russia & $3.9 \%$ & Oman & $8.8 \%$ \\
\hline
\end{tabular}

It is clear that Jordan is one of the top spenders in the world on its military. This fact, together with the weak status of public finance, if contextualized in their macroeconomic environment, one can argue the Jordanian government, one way or another, will soon face some difficult choices in the re-allocation process of resources and in reshuffling some policy priorities. Indeed, this is what one would expect, given the hitherto existing high unemployment rate, modest real economic growth, as well as the fact that during the period 2012-2019, the budget deficit was equivalent to 7.2 percent of GDP.

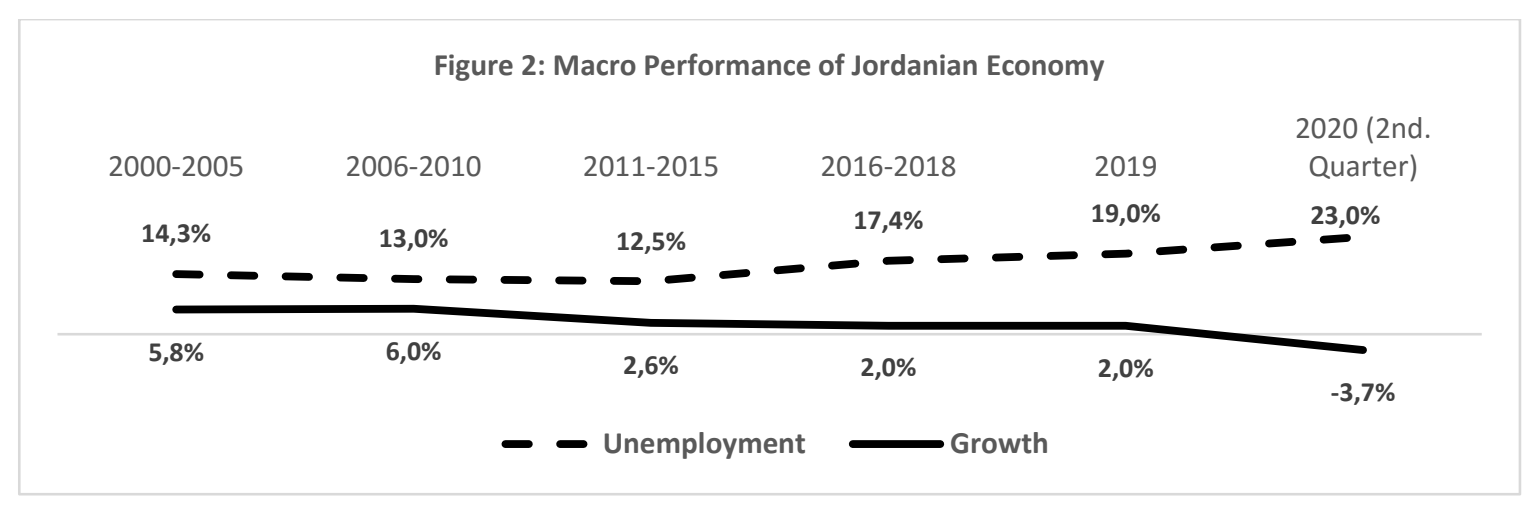


In Table 2, we present the unit root test (Dickey-Fuller) results. The results indicate that the three variables are not stationary in their level forms. However, they all become stationary at their first-difference levels.

Table 2: Augmented Dickey-Fuller Unit Root Test

\begin{tabular}{|l|c|c|c|c|c|c|}
\hline \multicolumn{1}{|c|}{ Variable } & \multicolumn{3}{|c|}{ Level } & \multicolumn{3}{c|}{ First-Difference } \\
\hline & None & Constant & $\begin{array}{c}\text { Constant \& } \\
\text { Trend }\end{array}$ & None & $\begin{array}{c}\text { Constant } \\
\text { Trend }\end{array}$ \\
\hline GDP & 3.343 & 0.261 & -2.155 & $-3.769^{*}$ & $-5.378^{*}$ & $-5.337^{*}$ \\
\hline MILITARY & 3.051 & -0.591 & -2.303 & $-5.225^{*}$ & $-6.199^{*}$ & $-6.114^{*}$ \\
\hline CREDIT & 8.124 & -1.921 & $-3.539 * * *$ & $-2.597^{* *}$ & $-4.134^{*}$ & $-4.036^{*}$ \\
\hline *Significant at the 99 percent confidence level.
\end{tabular}

Following the stationarity tests, we determine the optimal lag length (2), and estimate the Johansen co-integration test to examine the longterm co-integrating relationship among the three variables. In Tables 3 and 4, the results of the Johansen co-integration test are reported.

Table 3: Johansen Multivariate Co-Integration Test

\begin{tabular}{|c|c|c|c|c|}
\hline $\begin{array}{l}\text { Hypothesized No. of } \\
\text { CE(s) }\end{array}$ & Eigen Value & Trace Statistic & 5 percent CV & P-Value \\
\hline None* & 0.430 & 31.812 & 29.797 & 0.029 \\
\hline At most 1 & 0.235 & 10.40019 & 15.494 & 0.251 \\
\hline At most 2 & 0.006 & 0.215468 & 3.8414 & 0.643 \\
\hline
\end{tabular}

Table 4: Johansen Multivariate Co-Integration Test

\begin{tabular}{|c|c|c|c|c|}
\hline Hypothesized No. of CE(s) & Eigen Value & Trace Statistic & 5 percent CV & P-Value \\
\hline None* & 0.4308 & 21.411 & 21.131 & 0.046 \\
\hline At most 1 & 0.2351 & 10.184 & 14.264 & 0.200 \\
\hline At most 2 & 0.0056 & 0.215 & 3.841 & 0.643 \\
\hline
\end{tabular}

The trace and maximum eigenvalue statistics indicate that at least two co-integrating relationships exist. This also implies that there is a longrun relationship between the variables. When we estimate a two-lag Vector Error Correction Model, the negative and significant coefficient of the error correction term confirms the long-run equilibrium relationship between the three variables. These findings indicate that military spending and bank credit to the private sector jointly promote real economic growth.

$$
\text { Long-Run Relationship: InGDP } \mathrm{t}-1_{1}=15.002-0.497^{*} \text { MILITARY+0.821*CREDIT }
$$

Finally, when we run variance decomposition analysis, the results show that the variability in real economic growth is mostly lagged by its own variance. However, and over time, bank credit to the private sector increases in power in explaining the variability in real economic growth, and not military spending.

Table 5: Variance Decomposition Analysis

\begin{tabular}{|c|c|c|c|}
\hline Period & GDP & MILITARY & CREDIT \\
\hline 1 & 100.0000 & 0.000000 & 0.000000 \\
\hline 2 & 89.63981 & 5.274009 & 5.086183 \\
\hline 3 & 85.50920 & 3.328646 & 11.16215 \\
\hline 4 & 81.84993 & 2.161581 & 15.98849 \\
\hline 5 & 78.97057 & 1.616355 & 19.41307 \\
\hline 6 & 76.69518 & 1.459147 & 21.84567 \\
\hline 7 & 74.90189 & 1.502960 & 23.59515 \\
\hline 8 & 73.48006 & 1.633356 & 24.88658 \\
\hline 9 & 72.34286 & 1.792674 & 25.86447 \\
\hline 10 & 71.42360 & 1.952614 & 26.62379 \\
\hline
\end{tabular}

\section{CONCLUSIONS}

COVID-19 has forced many governments across the globe to implement some unprecedented fiscal policy measures, especially in its spending side. The extra spending measures will no doubt put pressure on budget deficits. Indeed, economies with relatively weak public finance (low tax and non-tax revenues), like Jordan, will be particularly vulnerable. The resultant deterioration in the budget deficit will probably force the Jordanian government to make difficult choices in re-allocating its resources. In other words, the pandemic might lead to some decrease in military spending. 
The fact that military spending is relatively high, and its impact on growth is negative, one can argue that the government should shift some resources from this sector (military) to other sectors such as health and education. However, such a decision would not be easy given the fact that Jordan is located in a politically and security unstable environment. After all, lack of security can be a major impediment to growth and development. Military spending maintains security per se.

\section{REFERENCES}

Abu-Bader, S. and Abu-Qarn, A.S. (2003). Government expenditures, military spending and economic growth: causality evidence from Egypt, Israel and Syria. Journal of Policy Modelling, 25: 567-583.

Aurelien, N., and K. Jean-Claude (2018). Military expenses: A brake on economic growth in Chad. International Journal of Development and Conflict, 8: 14-26.

Aurelien, N., A. Nchofoung, T. Marcel, and K. Jean-Claude (2019). Non-linear effect of military spending on economic growth in Africa: A comparative study between stable and unstable countries. International Journal of Development and Conflict, 9: 195-215.

Derouen, K. (2000). The guns-growth relationship in Israel. Journal of Peace, 37: 71- 83.

Lebovic, J. and A. Ishaq (1987). Military burden, security needs and economic growth in the Middle East. Journal of Conflict Resolution, March: 106- 138.

Mohanty, R., S. Panda, and B. Bhuyan (2020). Does defence spending and its composition affect economic growth in India?. The Journal of Applied Economic Research, 14: 62-85.

Sezgin, S. (2000). An empirical analysis of Turkey's defence - growth relationships with a multi-equation model (1956-1994). Defence and Peace Economics, 11: 63-80.

Yildirim, J. and Sezgin, S. (2002). A system estimation of the defense-growth relation in Turkey. In Arming the South: The Economics of Military Expenditure, Arms Production and Arms Trade in Developing Countries, edited by J. Paul Dunne and Jurgen Brauer. London: Palgrave, 319-335.

Yildirim, J., S. Sezgin, and N. Ocal (2005). Military expenditure and economic growth in Middle Eastern countries: A dynamic panel data analysis. Defence and Peace Economics, 16: 283 